\title{
THE ADMINISTRATION OF MUSLIM'S AND NON- MUSLIM'S OWNERLESS ESTATE (BONA VACANTIA) IN WEST MALAYSIA: AN ANALYSIS
}

\author{
Akmal Hidayah Halim \\ International Islamic University Malaysia. \\ (Email: akmalh@iium.edu.my) \\ Tajul Aris Ahmad Bustami \\ International Islamic University Malaysia \\ (Email: tajularis@iium.edu.my) \\ Wan Noraini Mohd Salim \\ International Islamic University Malaysia. \\ (Email: w.noraini@iium.edu.my) \\ Rahmawati Mohd Yusoff ${ }^{1}$ \\ International Islamic University Malaysia \\ (Email: rahmawatimohdyusoff@gmail.com)
}

Received date: $28-08-2019$

Revised date: 10-09-2019

Accepted date: 17-09-2019

Published date: 17-09-2019

To cite this document: Halim, A. H., Bustami, T. A. A., Salim, W. N. M., \& Yusoff, R. M. (2019). The Administration of Muslim's and Non-Muslim's Ownerless Estate (Bona Vacantia) West Malaysia: An Analysis. International Journal of Law, Government and Communication, 4(16), 26-34.

DOI: $10.35631 /$ ijlgc. 416003

\begin{abstract}
In Malaysia, if a deceased passed away intestate (without leaving a valid will) and no next of kin is available, his or her estate is deemed as an ownerless estate (bona vacantia). However, bona vacantia has not been classified, identified, and examined clearly, particularly in terms of the various sets of law applicable to the non-Muslims and Muslims in West Malaysia. Therefore, this paper intends to examine the classification of estates categorised under bona vacantia, its position in both Islamic law and Malaysian law, and the issues associated with the topic. The doctrinal analysis is adopted by analysing the current primary and secondary materials which include case law, statutory provisions, and other legal and non-legal literature. Consequently, the administration of bona vacantia is found to be governed by different procedures and laws, based on the personal law of the deceased. If he is a Muslim, his estate
\end{abstract}

\footnotetext{
${ }^{1}$ Akmal Hidayah Halim, Associate Professor, Department of Legal Practice, Ahmad Ibrahim Kulliyyah of Laws, International Islamic University Malaysia, Kuala Lumpur, Malaysia, Email: akmalh@iium.edu.my.

Tajul Aris Bin Ahmad Bustami, Assistant Professor, Department of Islamic Law, Ahmad Ibrahim Kulliyyah of Laws, International Islamic University Malaysia, Kuala Lumpur, Malaysia, Email: tajularis@iium.edu.my.

Wan Noraini Binti Mohd Salim, Assistant Professor, Department of Islamic Law, Ahmad Ibrahim Kulliyyah of Laws, International Islamic University Malaysia, Kuala Lumpur, Malaysia, Email: w.noraini@iium.edu.my. Rahmawati Mohd Yusoff, Postgraduate Candidate, Ahmad Ibrahim Kulliyyah of Laws, International Islamic University Malaysia, Kuala Lumpur, Malaysia, Email: rahmawatimohdyusoff@gmail.com.
} 
will be reverted to Baitulmal. Meanwhile, the type of estate left by a deceased non-Muslim will determine the reversion of such estate, either to the Government or the State Authority.

Keywords: Administration of Estate, Bona Vacantia, Muslim, Non-Muslim, Baitulmal, Government, State Authority, West Malaysia

\section{Introduction}

Bona vacantia is a Latin word which is defined as properties or goods without an owner. It is technically a legal concept related to properties without owner. Thus, if a deceased left no heir to inherit his estate, the property is deemed to be bona vacantia. The exact administration and management of bona vacantia differs based on the jurisdiction of each state. This research analyses the administration of bona vacantia, inter alia, for Muslims and non-Muslims in West Malaysia.

\section{Administration of Bona Vacantia in West Malaysia}

In Malaysia, the dual system has been exercised in matters of the estates, depending on the personal laws of the deceased. The Federal Constitution states that matters related to intestate, testate, and succession for Muslims are governed and determined by Islamic law. In contrast, the estates of non-Muslims are governed by specific acts such as the Civil Law Act 1956, the Inheritance (Family Provision) Act 1971, and the Distribution Act 1958.

Eventually, the administration of bona vacantia falls under the jurisdiction of different sets of personal laws. For the Muslims, the bona vacantia estates, either immovable or movable properties, are reverted to Baitulmal. Conversely, for non-Muslims, the movable properties are vested on Federal Consolidated Fund (YDPA Fund), whereas the immovable properties are accrued to the State Authority.

\section{Figure 1: The Administration of Bona Vacantia}

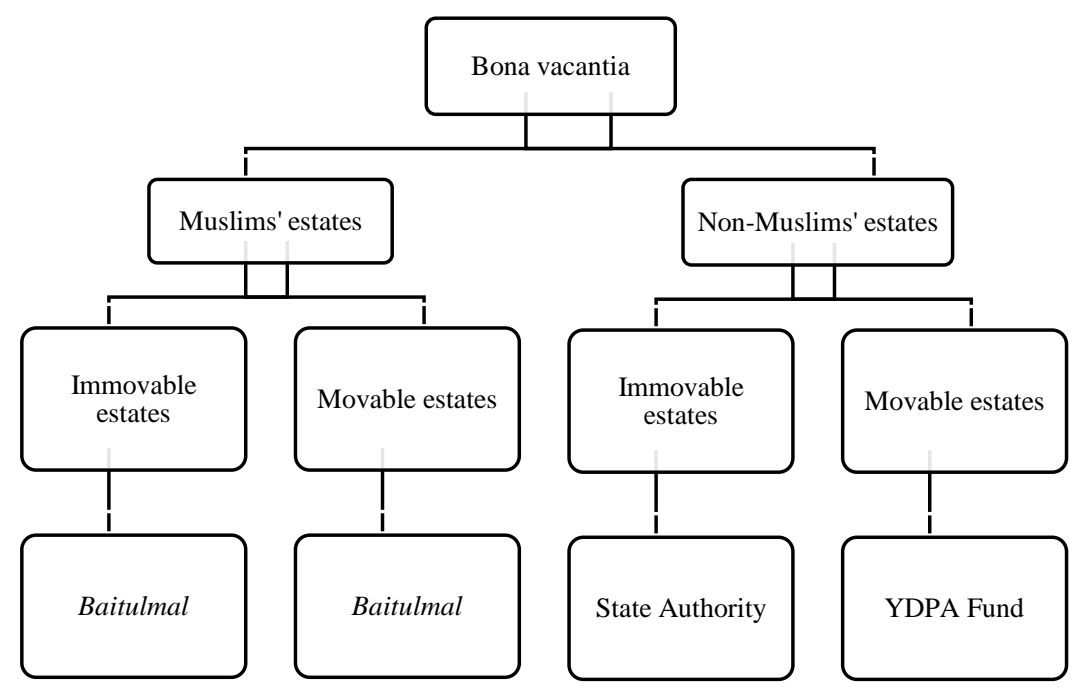




\section{The Administration of Bona Vacantia for Muslims}

In Malaysia, bona vacantia of Muslims are under the jurisdiction of the Federal Constitution, the Small Estates (Distribution) Act 1955, and the National Land Code 1965. In the Federal Constitution, the Islamic law is only applicable to the personal laws of Muslims, inter alia, in matters such as succession, intestate, testate, and Baitulmal. By virtue of Section 351 of National Land Code 1965, the law provides that in cases when the Land Administrator receives evidence and is satisfied that the proprietor of any alienated land has died, and no petition has been filed for a grant of representation to the estate of the original proprietor, and no petition for the distribution of that estate has been lodged under the Small Estates (Distribution) Act 1955, the Land Administrator shall declare that the original proprietor of the land appears to have died without successor, and that the land will be reverted to the State Authority. Nonetheless, this is always subject to the provisions of any law in force, which is currently related to Baitulmal. The right of Baitulmal in the deceased's estate has also been statutorily acknowledged in the proviso to Section 13(1) of the Small Estates (Distribution) Act 1955. The section provides that in the presence of any written law in force related to Baitulmal, prior to distributing any part of the estate of a deceased Muslim, the Land Administrator shall satisfy himself that any share of the estate which is due to the Baitulmal has been duly paid, or proper provision for the payment thereof has been made.

In Islamic law, the law of faraid states that Baitulmal will inherit the estate or its yield under three situations. First, a Muslim who is not survived by anyone to inherit his estate. Second, when no residuary heir takes the balance (asabah) of the property of the deceased.. Third, the legal heir may exist but is impeded from inheriting the property, for example, the heir falls under the category of dhawi al-arham (relatives), the heir practises different religion, or the heir had caused the death of deceased.

If only dhawi al-arham (relatives) of the deceased are traceable, the schools of thoughts by Maliki and Shafie rule that Baitulmal will inherit the particular estate provided that the institution is properly administered. Conversely, the schools of thoughts of Hanafi and Hanbali opine that the estates will be inherited by the dhawi al-arham (relatives) on the basis of arradd.

The scholars have different opinions based on the following hadith:

Narrated Al-Miqdam, I heard the Messenger of Allah (PBUH) say:

"I am the heir of him who has none, freeing him from his liabilities, and inheriting what he possesses. A maternal uncle is the heir of him who has none, freeing him from his liabilities, and inheriting his properties." (Abi Dawud).

Nevertheless, in Malaysia, the perspective of the schools of thoughts by Maliki and Shafie is prevalent. The properties of a deceased will be transferred to Baitulmal and utilised for the interest of the needy and the public, especially Muslims. This indicates that Baitulmal has higher right to the properties compared to the dhawi al-arham (relatives).

In addition, the bona vacantia rule for the estates of deceased Muslims may be understood via the following decided cases. In the case of Re Mutchilim Alias Ashrhin, Decd; Ji Mawar v. Attorney-General [1960] MLJ 25, the plaintiff was the widow of Mutchilim @ Ashrhin, and the deceased did not have any children or any other surviving family member. The issue in this case was the entitlement of the plaintiff as the widow of the deceased, whether to the entire estate of the deceased, or only to one-quarter share thereof while the remaining three-quarter 
share accrues to the Crown (Baitulmal). Notably, the deceased was a Muslim practising the Shafie school of thought and thus, based on the statement in the Minhaj et Talibin on the doctrine of radd, the plaintiff was not entitled to inherit the remaining of the deceased's properties. Accordingly, the plaintiff was beneficially entitled only to one-quarter share of the deceased's estate, whereas the remaining three-quarter share thereof was accrued to the Crown (Baitulmal).

Similarly, in Itam binti Saad v. Chik binti Abdullah [1974] 2 MLJ 53, the deceased had no male survivor and was survived by his widow and his daughter. Thus, the daughter was entitled to $7 / 16$ share, while the widow was entitled to $2 / 16$ share, whereas the remaining 7/16 share was accrued to Baitulmal.

Nonetheless, Baitulmal can allocate a portion of the inheritance to be distributed to other heirs via purchase through takharuj (relinquishing share of inheritance). This is demonstrated in the case of Abdul Malik bin Saham which is reported by Jabatan Wakaf, Zakat and Haji. The deceased was leaving a piece of land in Pontian, Johor. The deceased was survived by one heir, his sister, Jamilah binti Saham, who was entitled to $1 / 2$ of the land, while the balance of $1 / 2$ was to be handed over to Johor's Baitulmal. However, Jamilah submitted an application to redeem Baitulmal's portion on that particular land. After the applicant paid the redemption fee which amounted to RM37,000, the Baitulmal transferred the ownership of their portion of the particular land to the applicant.

As explained earlier, bona vacantia for Muslims also applies when the legal heir of the deceased is impeded from inheriting due to difference in religion. This normally happens when the deceased is a Muslim convert (muallaf) and left only non-Muslim heirs, and when a Muslim passes away as an apostate. For muallaf, the estate of the deceased can be considered as bona vacantia if a person converted to Islam and leave no Muslim survivor, based on a hadith from the Prophet (p.b.u.h).

Usama b. Zaid reported Allah's Messenger (p.b.u.h) as saying,

"A Muslim is not entitled to inherit from a non-Muslim, and a non-Muslim is not entitled to inherit from a Muslim." (Muslim)

In Malaysia, references on the distribution of inheritance involving Muslim and non-Muslim heirs are generally made on classical Islamic law. With the exception of court cases, no statute or by-law is dedicated to the topic.

The principle that the estate of muallaf will be transferred to Baitulmal if he leaves no Muslim heir is established in the case of In the Matter of the Estate and Effects of Timah binti Abdullah, Deceased the Official Administrator, FMS v. Magari Mohihiko Hayashi Tose Udah binti Akar State of Pahang [1941] MLJ 51. In this case, the deceased was a Japanese woman who married a Malay and converted to Islam. The husband of the deceased, who passed away before her, had resided in the state of Pahang together with his wife. In the husband's will, his wife was appointed to administer his estate and thus, the deceased became a beneficiary. However, the deceased passed away shortly after her husband's death. Accordingly, the Official Administrator was granted letters of administration with the annexed will of the estate of the husband and letters of administration of the estate of the deceased, respectively. The question was whether the next of kin of the deceased, who were non-Muslims, could inherit the property of the deceased. It was determined that non-Muslims are not entitled to inherit the estate of a 
Muslim. Hence, the state of Pahang was entitled to succeed to the estate, and her estate were transferred to the state via Baitulmal.

In the case of Majlis Agama Islam Wilayah Persekutuan v. Lim Ee Seng \& Anor [2000] 2 MLJ 572, the deceased had embraced Islam and was registered as a Muslim prior to his death. Subsequently, the letters of administration for the deceased's estate were issued to the defendants. The first defendant was the deceased's wife under civil law, who had two daughters with the deceased. The plaintiff had brought the case to the court in effort to revoke the letters of administration and request that the estate are given to her. However, the defendants counterclaimed this request by declaring that they were entitled to be the representatives and administrators of the deceased's estate. In this case, the issue was the defendants' entitlement to the estate of the deceased. The court held that as the deceased had embraced Islam and the defendants were not Muslims, the principle that a non-Muslim is forbidden from inheriting the estate of a Muslim applied to this case. The beneficial interest of the defendants in the estate of the deceased had never existed and hence, they had no right to inherit the deceased's estate. Accordingly, the court ordered the estate to be granted to the plaintiff, namely the Federal Territory Islamic Religious Council.

Apart from that, the case of In Application for Declaration Status Religion of Deceased Mohammad Abdullah @ Moorthy a/l Maniam JH XXI/II (1427H) highlights competing claims for the body of the deceased (Moorthy) between the Federal Territory Islamic Religious Council and his non-Muslim widow, Kaliammal. His family members were not aware of the fact that Moorthy had converted to Islam. Nevertheless, based on the ruling of Syariah Court, Kaliammal's declaration of Moorthy's religion status and claim of his body were dismissed. Against the wish of his widow, Moorthy was buried as a Muslim. As Moorthy had passed away intestate, his elder brother, Sugumaran @ Mohd Hussin Abdullah, became the sole heir to inherit Moorthy's estate because Sugumaran was also a Muslim convert and the only surviving Muslim family member. Nonetheless, Sugumaran had agreed to waive all his rights to the death benefits and transferred them to Kaliammal.

Similarly, in the case of Abdul Wahid Abdullah @ Lim Sek King (Abdul Wahid Lim) who had converted to Islam without his family's knowledge and passed away intestate. He left his nonMuslim wife and three sons aged 13, 12, and 5 years old, while the eldest son was suffering from a rare debilitating disease. The estate of the deceased which consisted of a medium-cost house, a low-cost house, and some savings was placed under the administration of the Malacca Islamic Religious Council (MAIM). After the death of the deceased, the widow had to work three jobs in order to raise their children. On humanitarian ground, in April 2005, MAIM had agreed to donate or release one of the deceased's houses or half of the deceased's estate to his surviving non-Muslim immediate family members, whereas the deceased's other house would be placed under Baitulmal.

In terms of apostate, the general rule is that an apostate does not belong to the religion of Islam anymore and when he passes away, both his Muslim or non-Muslim relatives do not have the right to inherit his property. Instead, his estate will be transferred to Baitulmal. A majority of scholars, namely the schools of thoughts of Maliki, Shafie, and xanbali, considered the estate of a murtad deceased as fayy' which will be transferred to Baitulmal. This opinion is formed based on the following hadith:

Usama bin Zaid reported the Prophet (p.b.u.h) as saying:

"A Muslim may not inherit from an infidel nor an infidel from a Muslim." (Abi Dawud). 
In contrast, Imam Abu Hanifah advocates a different opinion, namely the estate in the Muslim states, which was gained by the deceased while he was still a Muslim will be inherited by his beneficiaries, whereas the estate gained while he was an apostate is considered as fayy' and will be transferred to Baitulmal. Nonetheless, Imam Abu Hanifah made a reference to the $\mathrm{Al}$ Mawsu'ah Al-Fiqqiyyah Al-Kuwaitiyyah and differentiates between a female and a male apostate. The estate of a female apostate which was gained both while the deceased was still a Muslim and when she was an apostate will be inherited by her beneficiaries. Conversely, the estate of a male apostate which was gained while the deceased was still a Muslim will be inherited by his beneficiaries, while the estate gained when he was an apostate is considered as fayy' and will be transferred to Baitulmal.

Accordingly, in the case of Khairil Albrecht bin Abdullah German, the State Fatwa Committee of Selangor on behalf of Selangor Islamic Religious Council (MAIS) specified that the deceased was a Muslim at his time of death as he was still holding the Muslim Card issued by Muslim Welfare Organisation Malaysia (PERKIM). Khairil Albrecht bin Abdullah allegedly changed his religion to Christianity through a letter of oath before the Commissioner for Oaths and declaration in the newspaper. However, the committee decided that this is unacceptable and the claim that he died in Christianity is void. Additionally, the testimony of the oath which was witnessed by non-Muslims is illegal, and hence, the deceased was still a Muslim when he passed away. Nevertheless, the will to non-Muslims made by him is valid under the Islamic law, provided that it must not exceed one-third of the estate, while the balance shall be vested to Baitulmal.

Nevertheless, in Malaysia, the estate of a person who has been declared by the court to not be a Muslim anymore is governed by his personal law. Therefore, the rule on apostate as stated in the Islamic law which dictates that the deceased's estate is transferred to Baitulmal is not applied in this case. Consequently, the estate of a deceased apostate who left no heir will be transferred to the State Authority for immovable assets and the YDPA Fund for movable assets.

Meanwhile, an ex-parte application in the case of In the Matter of Application for Declaration Status Religion of Deceased Nyonya binti Tahir, The Application of Ex-parte State Islamic Religious Council of Negeri Sembilan, and 2 others JH XXI/II (1427H) was filed by the Negeri Sembilan Islamic Religious Council (MAIN), the Islamic Religious Department of Negeri Sembilan, and the Islamic religious official of Tampin. The application was made to determine the religion status of the deceased, Nyonya Tahir. The deceased was a Malay woman who had lived with her Chinese muallaf grandfather since her childhood and grew up with Chinese custom. Later on, she married a Chinese man and was blessed with 13 children from the marriage. Since her marriage up until the moment of her death, she worshipped Tok Kong and had never practised the Islamic way of life. Apart from that, she had written a declaration letter explaining that she had left Islam and expressed her wish to be buried according to the Chinese law after her death. In the decision-making process, the court also relied on other evidence categorised as qarinah, inter alia her worship of the Tok Kong placed in her house. As a result, the court decided that the deceased passed away as a non-Muslim and allowed the body to be buried by her beneficiaries according to the Chinese law.

\section{The Administration of Bona Vacantia for Non-Muslims}

The administration of bona vacantia for non-Muslims anticipates any custom which may divide and subsist the remainder of the estate according to the provisions of the Distribution Act 1958. By virtue of Section 4 of the Distribution Act 1958, the movable properties of a deceased non- 
Muslim will be governed by the Federal Laws, while the immovable properties will be governed by the State Laws.

Furthermore, the scheme of distribution of the intestacy is outlined under Section 6 of the Distribution Act 1958. As stated by Section 6(1)(a)-(i) of the Distribution Act 1958, in the absence of individual who takes absolute interest, the Government of Malaysia is entitled to the entire personal estate as bona vacantia.

Plus, the provision for bona vacantia of non-Muslims is presented in Section 24 of Civil Law Act 1956. Notably, when a right to the personal estate of any person who passed away intestate without next of kin has been granted to the Government, the personal estate or its proceeds shall be contributed to the Consolidated Fund for public purposes as directed and perceived to be proper by the Yang di-Pertuan Agong. Nonetheless, the Yang di-Pertuan Agong may order the transfer of the entire or any part of the personal estate or its proceeds by warrant to any person who could establish any moral or equitable claim to the satisfaction of the Yang di-Pertuan Agong.

Notably, the Federal Constitution holds that all revenues received or raised by the Federation through all means shall be subjected to the provisions of this constitution and the Federal Law. These revenues form one fund and are paid into the Federal Consolidated Fund. Apart from that, for ownerless immovable estates, Section 351 of National Land Code 1965 that outlines the death of a proprietor without successor provides that the alienated land shall be reverted to and vested in the State Authority.

In another case of Re Soo-Hoo Hem Leng [1963] 1 MLJ 38, Soo-Hoo Hong had made a will granting his houses to his sons, Soo-Hoo Hem Leng and Soo-Hoo Chuan Leng, and his grandson, Soo-Hoo Sheow Yew, as tenants-in-common in equal shares. Soo-Hoo Hem Leng was an adopted son, however, no evidence of any legal adoption proceedings existed. Later on, Soo-Hoo Hem Leng was taken to China by the second wife of the deceased, and ever since, he had disappeared with no sighting. Accordingly, Soo-Hoo Hem Leng's letters of administration to the estate was granted to the applicants. The issue is to ensure if Soo-Hoo Hem Leng had passed away with any ascertainable next of kin or if he had no survivor, whether his estate accrues to the Government of the Federation of Malaya as bona vacantia. Notably, no party had claimed that any legal adoption proceedings had taken place. Consequently, the court held that the deceased had passed away intestate and left no next of kin, thus, his estate was passed to the Federated Malay States Government as bona vacantia.

Furthermore, bona vacantia is also applicable when the deceased who is entitled to a pecuniary legacy under a will has died without next of kin, or in the presence of intestacy as to the residuary estate where construction of the will lack residuary clause and the testator has no next of kin. For example, in Re Will of Samuel Emily, deceased [2001] SGHC 299, in an intestacy as to the residuary estate of the testatrix, the court ordered that the residuary estate should be paid to the State after all expenses and gifts had been paid out, and no moneys have to be deposited into the Public Trustee for any period of time.

\section{Conclusion}

The administration of bona vacantia in West Malaysia are governed by a different set of personal laws and procedures, depending on the jurisdiction of each state. For Muslims, their estates are governed by the Federal Constitution, the National Land Code 1965, and the Small Estates (Distribution) Act 1955, and will devolve upon the Baitulmal. For non-Muslims, their 
estates are governed by the Civil Law Act 1956, the Distribution Act 1958, the National Land Code 1965, and the Federal Constitution. Particularly, their movable properties are reverted to the YDPA fund, while the immovable properties will accrue to the State Authority.

\section{Acknowledgement}

The authors fully acknowledge the sponsorship from the Malaysian Ministry of Higher Education Fundamental Research Grant Scheme (FRGS/1/2017/SSI10/UIAM/02/6) for the completion of this research project.

\section{References}

\section{Statutes}

Civil Law Act 1956

Distribution Act 1958

Federal Constitution

Inheritance (Family Provision) Act 1971

National Land Code 1965

Small Estates (Distribution) Act 1955

\section{Books and Articles}

Al-Qurtubi, Abu Umar Yusuf bin Abdullah bin Muhammad bin Abd al-Bir bin 'Asim al-Namri. (1980). al-Kafi fi Fiqh Ahl al-Madinah. Riyadh: Maktabah al-Riyadh al-Hadisah.

Abi Dawud, Sulayman ibn Al-Ash'ath Al-Azdi Al-Sijistani. (n.d). Sunan Abi Dawud. Beirut: Maktabah Al-Asriyah.

Akmal Hidayah Halim, Noor Azlina Mohd Noor, Azhani Arshad. (2018). Administration of Unclaimed Estates in Malaysia: The Peculiarities of Unclaimed Money, Undistributed Fund and Bona Vacantia. Journal of Social Sciences Research (JSSR), Vol. 4, No. 12.

Al-Khatib Al-Syirbini Al-Shafi'i, Shams Al-Din Muhammad ibn Muhammad. (1994). Mughni Al-Muhtaj ila Ma'rifah Ma'ani Alfaz Al-Minhaj. Dar Al-Kutub Al-'Ilmiyyah.

Al-Sabuni, Muhammad Ali. (1989). Al-Mawarith fi al-Syari'ah al-Islamiyyah fi Daui al-Kitab wa al-Sunnah. Beirut: Dar al-Fikr.

Al-Sarakhsi, Muhammad ibn Ahmad ibn Abi Sahl Shams. (1993). Al-Mabsut. Beirut: Dar AlMa'rifah.

Al-Zuhayli, Wahbah ibn Musïafa. (n.d). Al-Fiqh Al-Islami wa Adillatuh. Dimashq: Dar Al-Fikr.

An-Nawawi, Abu Zakaria Mahyuddin Yahya. (1991). Raudah at-Tolibin wa 'Umdah al-Muttaqin. Beirut: al-Maktab al-Islami.

Bona vacantia. (n.d). Retrieved January 19, 2019. http://www.dictionary.com/browse/bonavacantia.

Bona vacantia. (n.d). Retrieved January 19, 2019. https://en.wikipedia.org/wiki/Bonavacantia.

Faiz Hassan Badrudin Tyabji. (1940). Muhammadan Law: The Personal Law of Muslims. N. M. Tripathi.

Government of Selangor Gazette, 22nd October 1992, No. 1209.

Jabatan Wakaf, Zakat dan Haji, Jabatan Perdana Menteri (JAWHAR). (2018). Manual Pengurusan Tebus Pusaka. Malaysia: JAWHAR.

Jasni Sulong. (2014a). Hak Saudara Baru Terhadap Harta Pusaka: Analisis Undang-Undang Semasa. Journal of Islam and Contemporary Society, Vol. 8, p. 20.

Jasni Sulong. (2014b). The Implications of Religious Conversion towards Muslim Inheritance under Malaysian Law. International Journal of Liberal Arts and Social Science, Vol. 2, No. 9, p. 122. 
Jasni Sulong. (2008). Kedudukan Mazhab Syafi`I dalam Amalan Pembahagian Pusaka dan Wasiat Islam di Malaysia. Syariah Journal, Vol. 16, No. 1, p. 166.

Kuek Chee Ying, Tay Eng Siang. (2013). Religious Conversions and the Conflicts Between Civil and Islamic Law of Inheritance in Malaysia. Malayan Law Journal, 6 lxvi.

Md. Yazid Ahmad et al. (2018). Takharuj as an Effective Solution to the Inheritance Problems of Muslims. The Social Sciences, 13: 1094-1100.

Muslim, Abu Al-Husayn 'Asakir Al-Din Muslim ibn Al-Hajjaj ibn Muslim ibn Ward ibn Kawshadh Al-Qushayri Al-Naysaburi. (n.d). Sahih Muslim. Beirut: Dar Ihya' AlTurath.

Mustafa Al-Khin, Mustafa Al-Bugha, Ali Syarbini. (1992). Fiqh al-Manhaji 'ala Mazhab alImam Al-Shafi'i. Dimashq: Dar al-Qalam li al-Taba'ah wa al-Tauzi'.

Shalabi, M.M. (1978). Ahkam al-Mawarith Baina al-Fiqh wa al-Qanun. Beirut: Dar an-Nahdah al-Arabiyyah.

Sihombing, J. (2012). The Annotated Statutes of Malaysia on National Land Code. Malayan Law Journal Sdn Bhd.

Wan Noraini Mohd Salim. (2014). Islamic Law of Succession, A Practical Guide to the Laws of Faraid. Ampang, Selangor: The Malaysian Current Law Journal Sdn Bhd.

Wuzarah Al-Awqaf wa Al-Shuun Al-Islamiyyah. (1404-1427). Al-Mawsu'ah Al-Fiqqiyyah AlKuwaitiyyah. Egypt: Mutai’ Dar Al-Safwah.

\section{Cases Law}

In the Matter of the Estate and Effects of Timah binti Abdullah, Deceased the Official Administrator, FMS v Magari Mohihiko Hayashi Tose Udah binti Akar State of Pahang [1941] MLJ 51.

In Application for Declaration Status Religion of Deceased Mohammad Abdullah @ Moorthy a/l Maniam, JH XXI/II, (1427H).

In the Matter of Application for Declaration Status Religion of Deceased Nyonya binti Tahir, The Application of Ex-parte State Islamic Religious Council of Negeri Sembilan, and 2 others, JH XXI/II, (1427H).

Itam binti Saad v Chik binti Abdullah [1974] 2 MLJ 53.

Kaliammal a/p Sinnasamy v. Pengarah Jabatan Agama Islam Wilayah Persekutuan (JAWI) dan Lain-lain [2006] 1 MLJ 685.

Majlis Agama Islam Wilayah Persekutuan v Lim Ee Seng \& Anor [2000] 2 MLJ 572.

Re Mutchilim Alias Ashrhin, Decd; Ji Mawarv Attorney-General [1960] MLJ 25.

Re Soo-Hoo Hem Leng [1963] 1 MLJ 38.

Re Will of Samuel Emily, deceased [2001] SGHC 299. 